\title{
EFFECT OF NITRITE ON DENITRIFICATION OF WASTEWATER BY AUTOTROPHIC BACTERIA
}

\begin{abstract}
By :
Rudi Nugroho

Abstract.

Effect of nitrite on denitrification of synthetic wastewater using autotrophic bacteria was evaluated in both batch suspension and continuous packed column runs. Emphasis was placed to clarify the minimum concentrations of nitrite and nitrous acid that inhibit the denitrification rates. Batch suspension runs were conducted by mixing acclimatized denitrification sludge and synthetic wastewater in an Erlenmeyer flask. In continuous runs, denitrification sludge was loaded to a column packed with sulfur and limestone. The nitrite inhibition could be explained satisfactorily by substrate non-competitive inhibition model. The minimum concentration of nitrite which inhibits the nitrate and nitrite removal rate lowered with decreasing $\mathrm{pH}$. In suspension runs, the minimum concentration of nitrous acid which inhibited the nitrite removal rate was $0.043 \mathrm{~g}-\mathrm{N} / \mathrm{m}^{3}$, while the nitrate removal rates was inhibited below $0.012 \mathrm{~g}-\mathrm{N} / \mathrm{m}^{3}$. Both in suspension and continuous packed column runs, nitrate removal was more sensitive against nitrite increase compared with nitrite removal. The minimum concentration of nitrite which inhibited nitrate removal rate in continuous packed column runs was lower than that in suspension runs.
\end{abstract}

Keywords: Autotrophic bacteria, denitrification, inhibition, nitrite, sulfur

\section{INTRODUCTION}

The nitrate concentration of groundwater in many areas of the world has been increasing due to increased usage of fertilizer and increased discharge of domestic and industrial wastewater. In East Java, Indonesia, nitrate contaminant in household well water was observed up to 304 $\mathrm{g} / \mathrm{m}^{3}$ (68.6 $\left.\mathrm{g}-\mathrm{N} / \mathrm{m}^{3}\right)$, exceeding the limit that regulated by the government (Wetselaar et al., 1993). When the nitrate-contaminated water is taken in human body, nitrate is reduced to nitrite in the stomach followed by reacting with hemoglobin in blood, converting hemoglobin into methemoglobin, which cannot carry oxygen to cell tissue (Dahab and Lee, 1988). This phenomenon is called methemoglobinemia (blue baby syndrome). Nitrite may also lead to the formation of nitrosoamines, which are known carcinogens.

Nitrate and nitrite removal (denitrification) from wastewater containing sufficient organic compounds is effectively performed by heterotrophic bacteria. In this process, the organic carbon compounds involved in the wastewater are employed as a hydrogen donor. However, for example, nitric-acid rinsing process wastewater, nitrate-contaminated ground water and nitrified landfill leachate have low organic carbon/nitrogen ratio, and chemicals such as methanol are added to the wastewater to promote denitrification reaction. The cost for such chemicals lowers the efficiency of heterotrophic denitrification processes. In such cases, simple and economical denitrification using autotrophic bacteria is suitable. Thiobacillus denitrificans is typical autotrophic bacteria which can reduce nitrate by employing various sulfur compounds such as thiosulfate and elemental sulfur as an electron donor, without adding any organics compounds.

Denitrification process in wastewater treatment removes nitrogen by reducing nitrate to nitrogen gas through intermediate nitrite. When the reduction rate of nitrate to nitrite is faster than that of nitrite to nitrogen gas, accumulation of nitrite occurs. Moreover, lack of alkalinity causes the nitrite accumulation in the denitrification with autotrophic bacteria (Rudi et al., 2001; Furumai et al., 1996). Biomass buildup in the denitrification with sulfur and limestone packed column is also reported to cause the accumulation of nitrite in the treated wastewater (Flere and Zhang, 1999). The formation of nitrite is undesirable because it is more toxic level than nitrate. Nitrite is known as bacteriostatic agents due to the affinity to metal ions in the active center of enzymes (Wild et al., 1995). Hence, nitrite acts as an inhibitor in denitrification reaction. Several author reported that undissociated nitrous acid $\left(\mathrm{HNO}_{2}\right)$ inhibits denitrification using heterotrophic bacteria (Almeida et al., 1995; Glass et al., 1997). Nitrite concentration of about $30 \mathrm{~g}-\mathrm{N} / \mathrm{m}^{3}$ was reported to inhibit the denitrification reaction with autotrophic bacteria (Claus and Kutzner, 1985). However, these experiments were conducted only at $\mathrm{pH}$ 7.5. Therefore they could not elucidate the effect of undissociated nitrous acid. In the present study, the minimum concentration of nitrite and nitrous acid that inhibit autotrophic denitrification was investigated by performing both on batch suspension and continuous packed column runs at various $\mathrm{pH}$ with elemental sulfur as an electron 
donor.

\section{MATERIALS AND METHODS}

\subsection{Acclimation of microorganism}

To obtain the sludge capable of autotrophic denitrification, activated sludge taken from the municipal wastewater treatment plant was acclimatized by feeding the synthetic wastewater under anaerobic condition for a long time. The synthetic wastewater containing $144 \mathrm{~g} / \mathrm{m}^{3} \mathrm{KNO}_{3}$, $148 \mathrm{~g} / \mathrm{m}^{3} \mathrm{NH}_{4} \mathrm{Cl}, 122 \mathrm{~g} / \mathrm{m}^{3} \mathrm{MgSO}_{4} .6 \mathrm{H}_{2} \mathrm{O}, 10 \mathrm{~g} / \mathrm{m}^{3}$ FeSO ${ }_{4} .6 \mathrm{H}_{2} \mathrm{O}, 200 \mathrm{~g} / \mathrm{m}^{3} \quad \mathrm{KH}_{2} \mathrm{PO}_{4}, 1000 \mathrm{~g} / \mathrm{m}^{3}$ $\mathrm{NaHCO}_{3}$ and $300 \mathrm{~g} / \mathrm{m}^{3} \quad \mathrm{Na}_{2} \mathrm{~S}_{2} \mathrm{O}_{3} .5 \mathrm{H}_{2} \mathrm{O}$ (or 170 $\mathrm{g} / \mathrm{m}^{3}$ Sulfur powder). After denitrification activity of acclimatized sludge became appreciable, an electron donor was changed from $\mathrm{Na}_{2} \mathrm{~S}_{2} \mathrm{O}_{3}$ to sulfur powder and the acclimation was continued.

\subsection{Batch denitrification in suspension runs}

The batch denitrification runs were conducted in $300 \mathrm{ml}$ Erlenmeyer flask by mixing $100 \mathrm{ml}$ of synthetic wastewater and $100 \mathrm{ml}$ of acclimatized sludge under various $\mathrm{pH}$ and initial nitrogen concentration. The synthetic wastewater contained $\mathrm{KNO}_{3}, \mathrm{NaNO}_{2}, \mathrm{KH}_{2} \mathrm{PO}_{4}$ and $\mathrm{NaOH}$. The concentration of these chemicals was changed depending on the initial nitrogen concentration and $\mathrm{pH}$ value. $\mathrm{pH}$ was varied between 6 to 7. To keep anaerobic condition, a flask was equipped with rubber lid after purging with nitrogen gas and shaken at 30 during reaction. After sampling, nitrogen gas was purged into the flask about 3 minute to keep anaerobic condition.

\subsection{Continuous denitrification in packed column}

A column made of acrylic pipe, $40 \mathrm{~mm}$ in diameter and $150 \mathrm{~mm}$ in height, was filled with mixture of granular sulfur and limestone. Limestone was used to suppress the decrease of alkalinity caused by proton released during autotrophic denitrification. The volume ratio of sulfur to limestone was set at 1:1. Both sulfur and limestone particles were in the range of 2.8 to 4 $\mathrm{mm}$. The acclimatized sludge was loaded in the column and recycled through the column to form biofilm on the granule. To operate the packed column run just like CSTR, the column was equipped with mixing tank. The synthetic wastewater was fed $1.5 \mathrm{ml} / \mathrm{min}$ continuously to the mixing tank while the wastewater was recycled between the mixing tank and the packed column with the flow rate of $15 \mathrm{ml} / \mathrm{min}$. The synthetic wastewater was composed of $\mathrm{KNO}_{3}$ fixed with concentration of $60 \mathrm{~g}-\mathrm{N} / \mathrm{m}^{3}$ and $\mathrm{NaNO}_{2}$ with the concentration between 0 to $100 \mathrm{~g}-\mathrm{N} / \mathrm{m}^{3}$. Any minerals essential for bacterial growth consisted of $148 \mathrm{~g} / \mathrm{m}^{3} \quad \mathrm{NH}_{4} \mathrm{Cl}, 122 \mathrm{~g} / \mathrm{m}^{3}$
$\mathrm{MgSO}_{4} .6 \mathrm{H}_{2} \mathrm{O}, 5 \mathrm{~g} / \mathrm{m}^{3} \mathrm{FeSO}_{4} .6 \mathrm{H}_{2} \mathrm{O}$, and $4.5 \mathrm{~g} / \mathrm{m}^{3}$ $\mathrm{KH}_{2} \mathrm{PO}_{4}$ were added to the synthetic wastewater. To keep $\mathrm{pH}$ during continuous operation, $\mathrm{pH}$ control system was installed in the mixing tank. Samples were taken daily from the feed tank at inlet and from the mixing tank at outlet. Nitrate and nitrite concentration was analyzed by using ion chromatography.

\subsection{Kinetics analysis}

Denitrification reaction kinetics with autotrophic bacteria was investigated based on the enzymatic reaction model. The effect of nitrite on the reaction rate was analyzed by substrate non-competitive inhibition model. In the denitrification runs using nitrite only as a nitrogen source, inhibition by nitrite was described by the following substrate inhibition model as shown in Eq. (1).

$$
\frac{v}{v_{\max }}=\frac{1+2 \sqrt{\frac{K_{m}}{K_{i}}}}{1+\frac{K_{m}}{S}+\frac{S}{K i}}
$$

In the case of both nitrate and nitrite existing in the synthetic wastewater, we assumed that nitrite acted as an inhibitor of nitrite removal. In this case, a non-competitive inhibition model was applied as shown by Eq. (2) to investigate the effect of nitrite on nitrate removal rates.

$$
\frac{v}{v_{\max }}=\frac{K_{i}}{K_{i}+I}
$$

where $v / v_{\max }$ is relative denitrification rate with $V_{\max }$ is non-inhibited denitrification rate. $K_{\mathrm{i}}$ is the inhibition coefficient, and $K_{m}$ is Michaelis constant. $S$ and $I$ mean substrate concentration and inhibitor, respectively.

\section{RESULTS AND DISCUSSION}

\subsection{Denitrification of nitrite in batch suspension runs}

Figure 1 shows nitrite removal behavior using nitrite as a nitrogen source at $\mathrm{pH} 6,6.5$ and 7. As shown in these figures, nitrite decreased linearly in all runs showing zero-order reaction. Nitrite removal rate was calculated from the slope of those regression lines. At pH 6, the slope of the linear regression lines decreased with increasing the initial nitrite from 20 to $95 \mathrm{~g}-\mathrm{N} / \mathrm{m}^{3}$. At pH 6.5, the slopes for initial nitrite concentration up to 110 $\mathrm{g}-\mathrm{N} / \mathrm{m}^{3}$ were almost parallel. However, the slope was low when the initial concentration was 130 
$\mathrm{g}-\mathrm{N} / \mathrm{m}^{3}$. This show that at $\mathrm{pH} 6.5$ the nitrite concentration of $130 \mathrm{~g}-\mathrm{N} / \mathrm{m}^{3}$ inhibited the denitrification of nitrite. At higher $\mathrm{pH}$ of 7 , the slope of the linear regression was same even at initial concentration of $300 \mathrm{~g}-\mathrm{N} / \mathrm{m}^{3}$. We reported that nitrite reduction activity was optimum at $\mathrm{pH}$ around 6.5 (Kwon et al., 2001). These experimental results show that nitrite reduction rate was highest at $\mathrm{pH} 6.5$.

Figure 2 shows the effect of initial nitrite concentration on denitrification of nitrite at different $\mathrm{pH}$. From this figure, it is clearly shown that the nitrite concentration which inhibit the denitrification was different by $\mathrm{pH}$ condition. The nitrite removal rate decreased with increasing the initial nitrite concentration at $\mathrm{pH} 6$. At $\mathrm{pH} 6.5$, the nitrite removal rate decreased when the initial nitrite concentration exceeded $130 \mathrm{~g}-\mathrm{N} / \mathrm{m}^{3}$. In contrast, almost the same rate was observed at $\mathrm{pH}$ 7. The decrease of denitrification might be caused by simultaneous inhibition effects of substrate and undissociated nitrous acid $\left(\mathrm{HNO}_{2}\right)$. The value of inhibition coefficient by nitrite $\left(K_{i}\left(\mathrm{NO}_{2}\right)\right.$ ) was calculated by fitting the experimental data with Eq. (1) as shown in Table 1. The $K_{i}(\mathrm{NO} 2)$ value increased with increasing $\mathrm{pH}$. The higher the
$K_{\mathrm{i}(\mathrm{NO} 2)}$ value, the higher the minimum nitrite concentration which inhibits the nitrite reduction. The increase of $K_{\text {i(NO2) }}$ with increasing $\mathrm{pH}$ shows that undissociated nitrous acid is the dominant inhibitor on nitrite reduction rate. Nitrous acid is weak acid with $\mathrm{pKa}$ of 3.13 at 30 . At $\mathrm{pH} 7$, the molar concentration of nitrous acid is about $0.01 \%$ of the total nitrite ion. However, nitrous acid is toxic to bacteria at low concentration (Glass et al., 1997; Almeida et al., 1995). Nitrous acid concentration was calculated using initial nitrite concentration, $\mathrm{pH}$ and dissociation constant of nitrous acid (Eq.3).

$$
\mathrm{HNO}_{2} \rightleftarrows \mathrm{H}^{+}+\mathrm{NO}_{2}^{-} \quad \mathrm{pKa}_{30}{ }^{\circ} \mathrm{C}=3.13 \quad(3)
$$

Plots of the relative nitrite removal rate versus nitrous acid concentration showed that the inhibition by nitrous acid occurred at the minimum concentration of $0.043 \mathrm{~g}-\mathrm{N} / \mathrm{m}^{3}$ (Figure 3 ). Glass et al., (1997) reported almost the same value of 0.04 $\mathrm{g}-\mathrm{N} / \mathrm{m}^{3}$ using activated sludge.
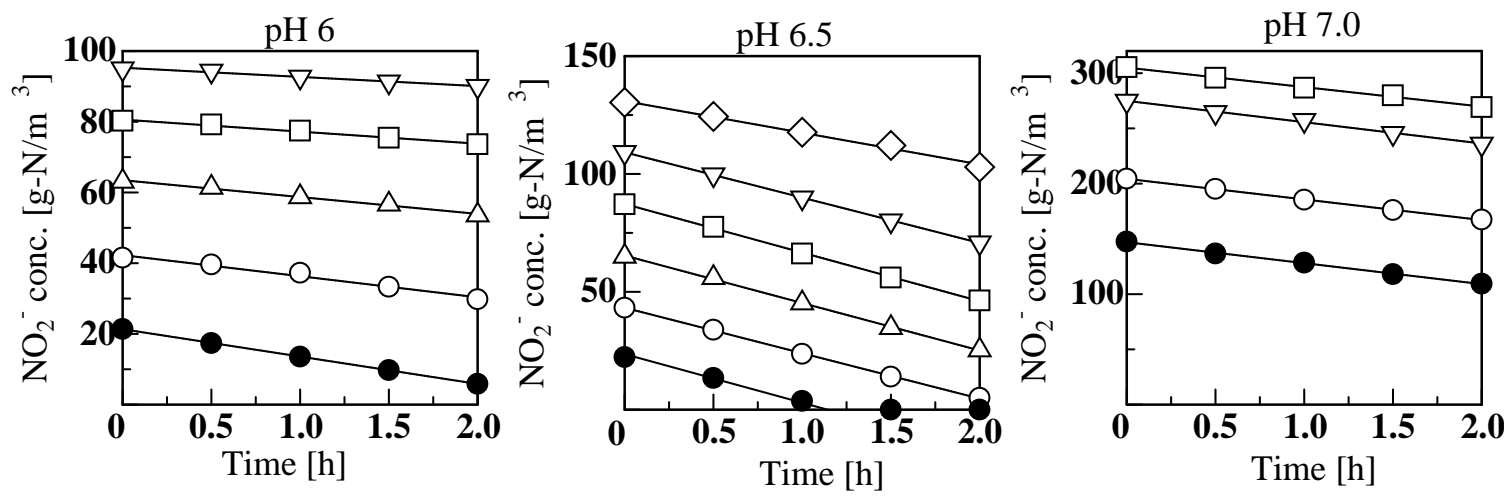

Figure 1. Nitrite concentration profile in batch suspension runs using nitrite as a nitrogen source
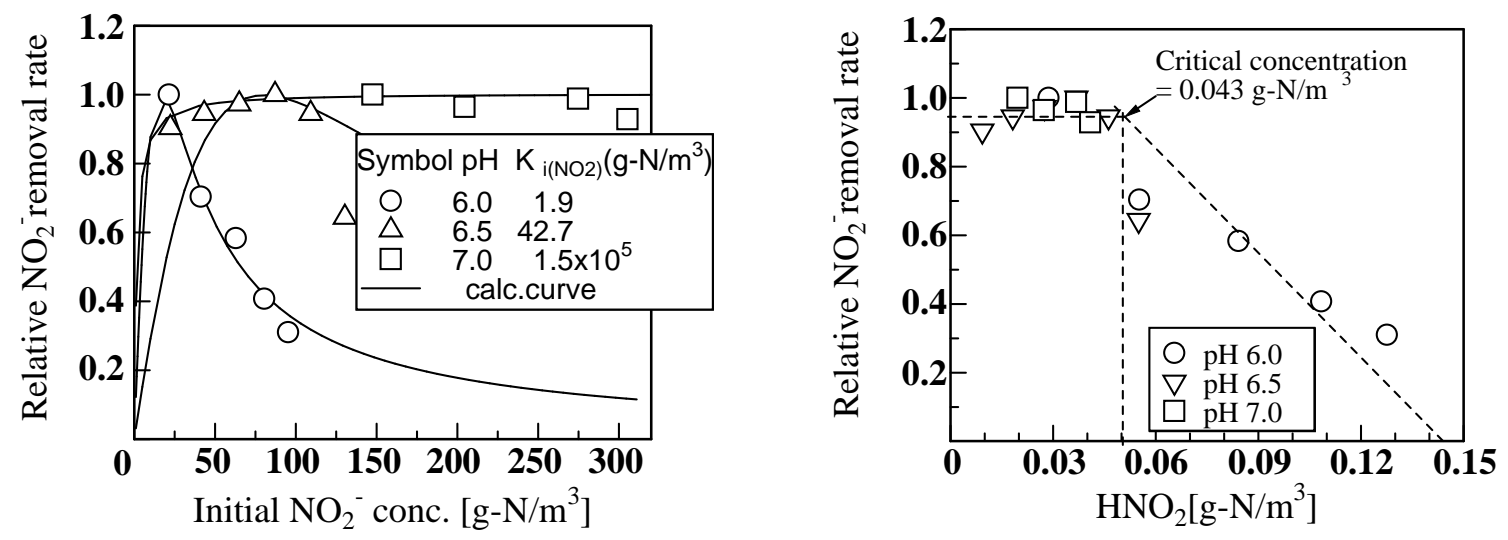

Figure 2. Effect of nitrite on nitrite removal rate. 
Figure 3. Effect of nitrous acid on nitrite removal rate
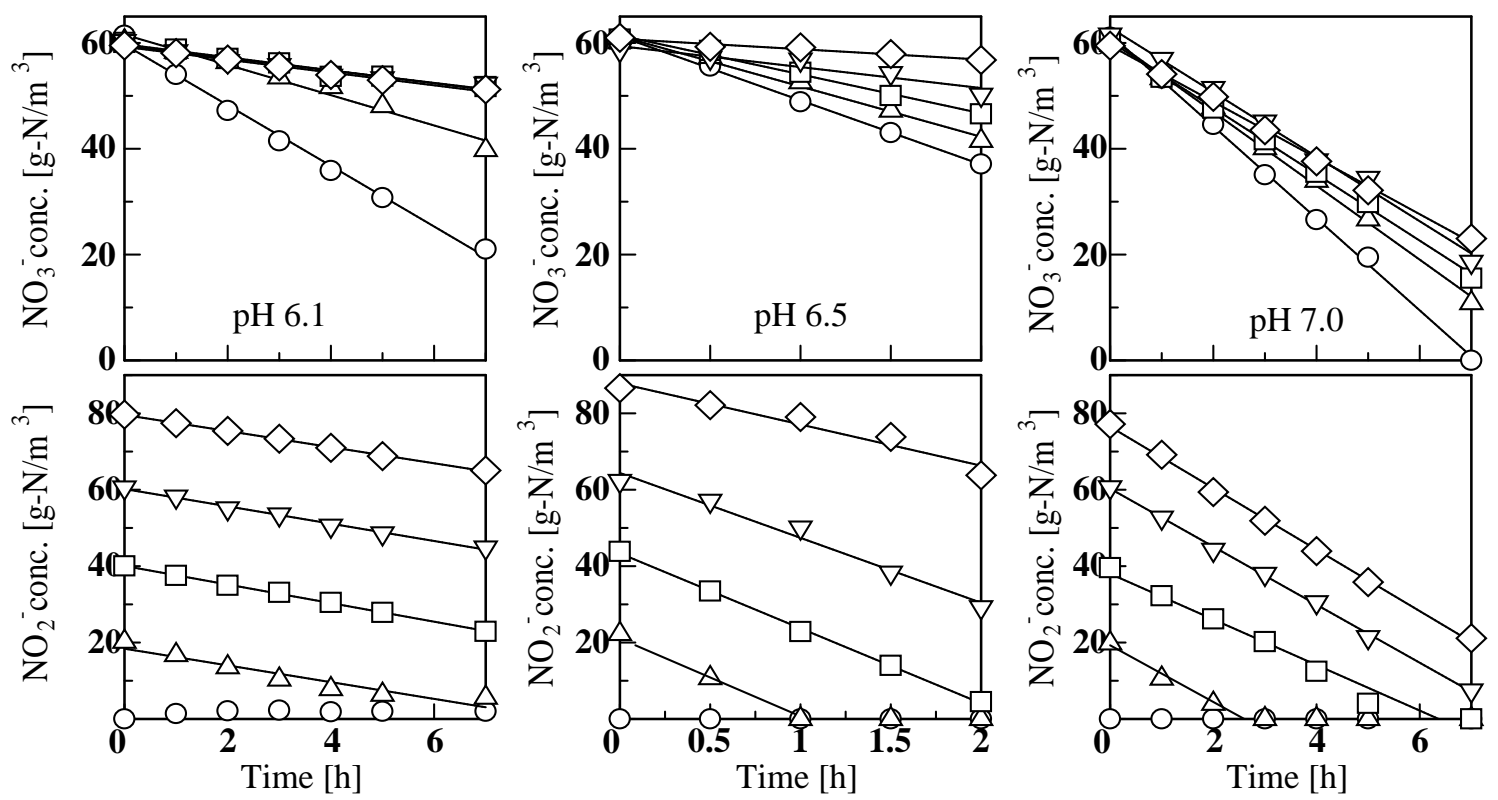

Figure 4. Nitrate and nitrite concentration profile in batch suspension runs using nitrate and nitrite as nitrogen source.

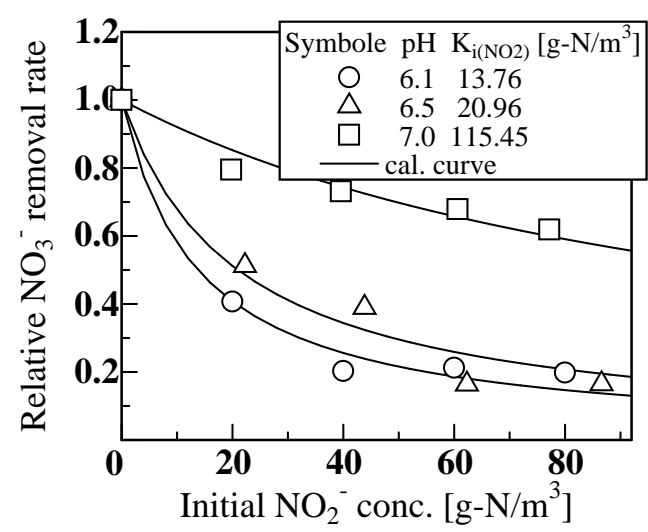

Figure 5. Effect of nitrite on nitrate removal rate

\subsection{Denitrification of nitrate and nitrite in batch suspension runs}

To investigate the extent of nitrite inhibition on nitrate removal, the runs were performed in batch suspension with nitrate and nitrite as initial reactant. Here, the nitrate removal means the reduction of nitrate to nitrite. The nitrate concentration was set at constant value of 60 $\mathrm{g}-\mathrm{N} / \mathrm{m}^{3}$, while nitrite concentration varied from 0 to $80 \mathrm{~g}-\mathrm{N} / \mathrm{m}^{3}$. Figure 4 shows the time courses of

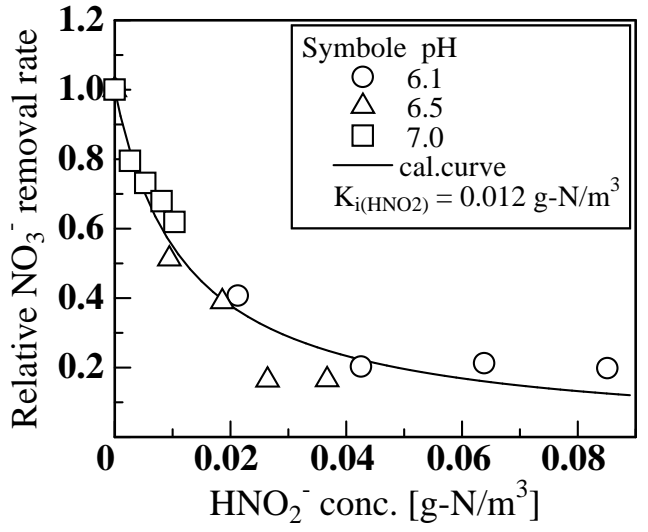

Figure 6. Effect of nitrous acid on nitrate removal rate

denitrification at $\mathrm{pH} 6.1,6.5$ and 7.0. Both nitrate and nitrite concentration decreased linearly with time in all $\mathrm{pH}$ condition, showing that the rate of nitrite reduction was higher than that of nitrate reduction. A linear regression was tried to fit the concentration profile with the slope equal to denitrification rate. The slope of nitrate concentration profiles decreased with increasing the initial nitrite concentration, suggesting that nitrite inhibited nitrate reduction rate. However, the slopes of nitrite concentration profile were 
almost parallel even at low $\mathrm{pH}$.

Figure 5 shows the plots of relative nitrate removal rate versus initial nitrite concentration. The calculation curve was drawn by using non-competitive inhibition model Eq. (2). The calculation line was close to the experimental results. This finding suggests that the inhibition by nitrite on denitrification can be modeled satisfactorily by non-competitive inhibition with nitrite as an inhibitor. The value of $K_{1}\left(\mathrm{NO}_{2}\right)$ was estimated from the calculation curve as shown in Table 1. It was found that at same $\mathrm{pH}$ the value of $K_{1}\left(\mathrm{NO}_{2}\right)$ for nitrate removal was lower than that for nitrite removal rate in the experiments using nitrite as nitrogen source, suggesting that nitrate reductase is more sensitive to nitrite inhibition than nitrite reductase. Moreover, $\mathrm{K}_{(\mathrm{NO} 2)}$ increased with the increase of $\mathrm{pH}$, that is, nitrous acid is also the dominant inhibitor in nitrate removal. Figure 6 shows the correlation between initial concentration of nitrous acid and relative nitrate removal rate. The line calculated by non-competitive inhibition model with $K_{\mathrm{i}(\mathrm{HNO})}$ of $0.012 \mathrm{~g}-\mathrm{N} / \mathrm{m}^{3}$ could satisfactorily fit the experimental data. In comparison with the nitrite removal rate, the value of $K_{\text {i }(\mathrm{HNO})}$ was significantly low. It means that the nitrate reductase is more sensitive to nitrous acid inhibition. Therefore, it is necessary to avoid the accumulation of nitrite for autotrophic denitrification.

\subsection{Continuous denitrification of nitrate and nitrite in packed column}

The effect of nitrite was studied in the continuous denitrification with a packed column. The experiments were conducted at $\mathrm{pH} 6.5$ with constant influent concentration of nitrate while changing the nitrite concentration. Figure 7 shows the time courses of continuous denitrification run. As shown in this figure, nitrate concentration at the outlet increased with increasing the influent nitrite concentration. When the influent nitrite was $60 \mathrm{~g}-\mathrm{N} / \mathrm{m}^{3}$ or more, nitrate removal almost could not proceed. However, the fraction of reduced nitrite increased with increasing the influent nitrite. Since the continuous experiments were operated just like CSTR, the concentration of all species was same in the whole reactor. Therefore, the effect of nitrite was investigated by plotting effluent nitrite concentration versus removal rate, as shown in Figure 8. Both removal rate and effluent nitrite concentration were average values calculated from Figure 7. When nitrate and nitrite were present in the influent, nitrite removal rate was calculated from the difference concentration of nitrate and nitrite in the effluent and influent, divided by hydraulic retention time of the reactor. As shown in Figure 8, nitrite clearly affected the nitrate removal rate. From the curve fitting with a non-competitive inhibition model, the value of $K_{(\mathrm{NO})}$ was determined as $5.86 \mathrm{~g}-\mathrm{N} / \mathrm{m}^{3}$ for nitrate removal rate, which was lower than that in suspension runs $\left(20.96 \mathrm{~g}-\mathrm{N} / \mathrm{m}^{3}\right)$. In the denitrification with sulfur and limestone packed column, diffusion of substrate through biofilm controlled the substrate removal rate (Rudi et al., 2001). When the substrate was nitrate and nitrite, we supposed that there is a competition for substrate to diffuse in biofim. Therefore, the diffusion rates of nitrate become slow when nitrite present, resulting simultaneous effects of diffusion competition and nitrite inhibition. Consequently, the minimum nitrite inhibition concentration in continuous packed column runs was lower than that in batch suspension runs. In contrast, nitrite removal rate in Figure 8 slightly increased with increasing nitrite concentration, suggesting that nitrite did not inhibit nitrite removal in continuous denitrification with sulfur and limestone packed column. This is because the range of nitrite concentration in a mixing tank was lower than its minimum inhibition concentration in batch suspension runs at $\mathrm{pH} 6.5$ $\left(42.7 \mathrm{~g}-\mathrm{N} / \mathrm{m}^{3}\right)$. In addition, the denitrification of wastewater with sulfur and limestone packed column obeyed a half-order reaction, resulting the rate increase with increasing substrate concentration (Rudi et al., 2001). The slight increase of nitrite removal rate in Figure 8 was supposed as the characteristic of half-order reaction.

\section{CONCLUSIONS}

Nitrite inhibited the denitrification reaction rate with autotrophic bacteria. The nitrite inhibition could be modeled by substrate inhibition and non-competitive inhibition equation. The minimum concentration of nitrite that inhibited nitrate and nitrite removal rate increased with the increase of $\mathrm{pH}$, suggesting that the inhibition by undissociated nitrous acid was dominant. In suspension runs, the minimum concentration of nitrous acid that inhibited the nitrite removal rate was $0.043 \mathrm{~g}-\mathrm{N} / \mathrm{m}^{3}$, while Inhibit the nitrate removal rates was $0.012 \mathrm{~g}-\mathrm{N} / \mathrm{m}^{3}$. Both in suspension and continuous packed column runs, nitrate removal was found to be more sensitive to nitrite compared nitrite removal. The minimum concentration of nitrite that inhibited nitrate removal in continuous packed column runs was lower than that in suspension runs. This might be caused by simultaneous effect of substrate diffusion competition and nitrite inhibition.

\section{References}

1. Almeida, J.S., S. M. Julio, M. A. M. Reis and M. J. T. Carrondo, Nitrite inhibition of denitrification by pseudomonas fluorescens. Biotechnology and Bioengineering, 46, 3, 194-201 (1995).

2. Claus, G., and H. J. Kutzner, Physiology and 
kinetics of autotrophic denitrification by thiobacillus denitrificans. Applied Microbiology and Biotechnology, 22, 283-288 (1985).

3. Dahab, M. F., and Y. W. Lee, Nitrate removal from water supplies using biological denitrification. Journal WPCF., 60, 9, 1670-1674(1988).

4. Furumai, H., H. Tagui, and K. Fujita, Effect of $\mathrm{pH}$ and alkalinity on sulfur-denitrification in a biological granular filter, Water Science Technology, 34, 1-2, 355-362(1996).

5. Flere, J. M., and T. C. Zhang, Nitrate removal with sulfur-limestone autotrophic denitrification processes. Journal of Environmental Engineering, 125, 8, 721-729(1999).

6. Glass, C., J. Silverstein and J. Oh, Inhibition of denitrification in activated sludge by nitrite. Water Environment Research, 69, 6, 1086-1093 (1997).
7. Kwon, T., N. Rudi, H. Takanashi, M. Hirata, and T. Hano, Effect of nitrite in autotrophic denitrification by thiobacillus denitrificans. Proc.of the $14^{\text {th }}$ Symp.on Chem. Eng. Korea-Japan (2001).

8. Rudi, N., T. Kwon, H. Takanashi, M. Hirata, and T. Hano, Development of autotrophic denitrification for treatment nitrate-contaminated industrial wastewater. Proceeding of Reg. Symp. on Chem. Eng., 2 (2001).

9. Wetselaar, R., J. J. Fox, G. D. Smith, M. R. Ali, R. J. Moermanto, and I. Achmad, Groundwater nitrate in East Java. J. Aust. Geol. Geophys., 12, 2/3, 273-277(1993).

10. Wild, D., R. von Schulthess and W. Gujer, Structured modeling of denitrification intermediates. Water Science and technology, $31,2,45-54(1995)$

\section{APPENDIX}

Table 1. Effect of nitrite and nitrous acid on denitrification in batch suspension runs. ( $K_{\mathrm{i}}$ was calculated from calculation curve in Fig. 2, 3, 5, 6 and 8)

\begin{tabular}{|c|c|c|c|c|c|c|c|}
\hline \multicolumn{3}{|c|}{ Batch run with $\mathrm{NO}_{2}{ }^{-}$only } & \multicolumn{3}{|c|}{ Batch run with $\mathrm{NO}_{2}^{-}$and $\mathrm{NO}_{3}^{-}$} & \multicolumn{2}{|c|}{$\begin{array}{l}\text { Continuous run with } \\
\mathrm{NO}_{2}^{-} \text {and } \mathrm{NO}_{3}^{-}\end{array}$} \\
\hline $\mathrm{pH}$ & \multicolumn{2}{|c|}{$\mathrm{NO}_{2}{ }^{-}$removal } & $\mathrm{pH}$ & \multicolumn{2}{|c|}{$\mathrm{NO}_{3}{ }^{-}$removal } & $\mathrm{pH}$ & $\mathrm{NO}_{3}{ }^{-}$removal \\
\hline \multirow[b]{2}{*}{6.0} & $\begin{array}{l}K_{i(\mathrm{NO} 2)} \\
{\left[\mathrm{g}-\mathrm{N} / \mathrm{m}^{3}\right]}\end{array}$ & $\begin{array}{l}K_{\mathrm{i}(\mathrm{HNO} 2)} \\
{\left[\mathrm{g}-\mathrm{N} / \mathrm{m}^{3}\right]}\end{array}$ & \multirow[b]{2}{*}{6.1} & $\begin{array}{l}K_{\mathrm{i}(\mathrm{NO} 2)} \\
{\left[\mathrm{g}-\mathrm{N} / \mathrm{m}^{3}\right]}\end{array}$ & $\begin{array}{l}K_{\mathrm{i}(\mathrm{HNO} 2)} \\
{\left[\mathrm{g}-\mathrm{N} / \mathrm{m}^{3}\right]}\end{array}$ & \multirow{4}{*}{6.5} & $K_{\mathrm{i}(\mathrm{NO} 2)}\left[\mathrm{g}-\mathrm{N} / \mathrm{m}^{3}\right]$ \\
\hline & 1.9 & & & 13.76 & \multirow{3}{*}{0.012} & & \multirow{3}{*}{5.86} \\
\hline 6.5 & 42.7 & 0.043 & 6.5 & 20.96 & & & \\
\hline 7.0 & 153473 & & 7.0 & 115.45 & & & \\
\hline
\end{tabular}

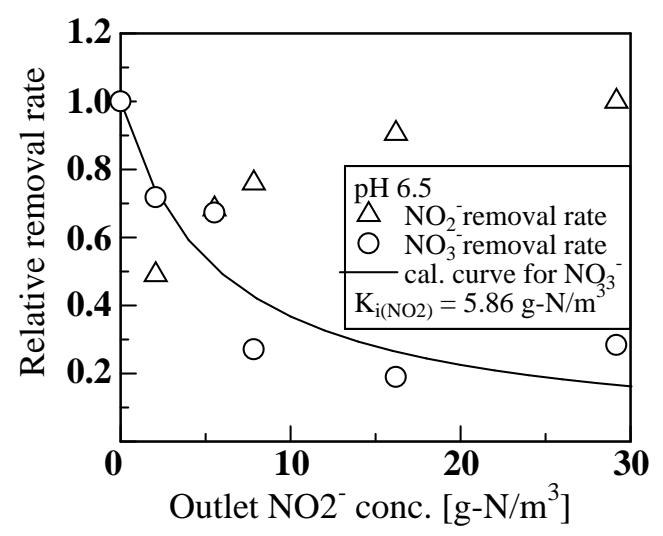

Figure 7. Time courses of denitrification in continuous runs

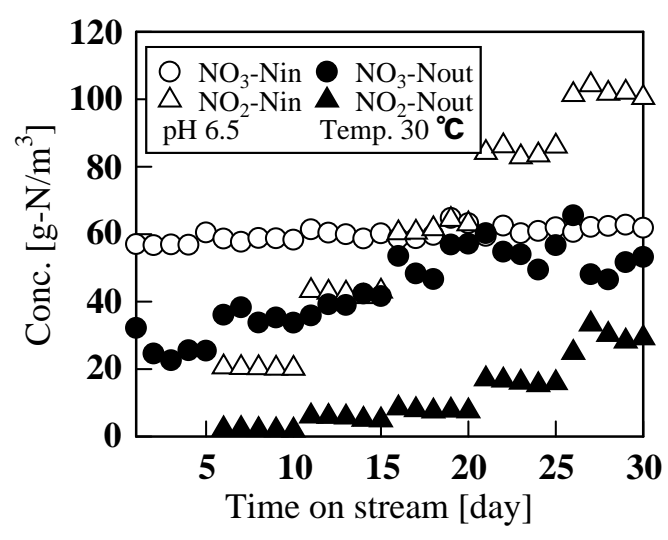

Figure 8. Effect of nitrite on nitrate and nitrite removal rate in continuous runs 